\title{
Distribution of gold, arsenic, and antimony in West and South Greenland: a guide to mineral exploration and environmental management
}

Agnete Steenfelt

The search for gold deposits has been a part of human activity as far back as history goes. The most popular exploration method for gold has been panning, a technique still widely used in both exploration and exploitation. In the first half of this century, geochemical exploration methods based on chemical analysis of systematically collected samples were developed and used successfully in the search for a range of ore deposits. However, direct geochemical exploration for gold $(\mathrm{Au})$ was not feasible until the 1980 s due to the insufficiency of analytical methods to determine the very small concentrations of $\mathrm{Au}$ in common rocks and surficial deposits.

In the early period of geochemical exploration arsenic (As) and antimony ( $\mathrm{Sb}$ ) were commonly used as so called pathfinder elements for $\mathrm{Au}$ (Boyle, 1979). The name is given because of the common association of gold mineralisation with rocks enriched in arsenopyrite (FeAsS) and/or stibnite $\left(\mathrm{Sb}_{2} \mathrm{~S}_{3}\right)$, and because As and $\mathrm{Sb}$ were easier to determine analytically due to their higher abundances. Many cases reported in the literature have documented the frequent association of $\mathrm{Au}$ with $\mathrm{As}$ and $\mathrm{Sb}$, and $\mathrm{As}$ and $\mathrm{Sb}$ anomalies in geochemical surveys are still considered indicative of gold mineralisation, particularly where the anomalies coincide (e.g. Plant et al., 1991). However, more and more cases are also described where Au mineralisation is not associated with As and $\mathrm{Sb}$. For example this applies to shear or fault zone hosted Au deposits in granitoid rocks.

Ten to twenty years ago the analytical situation with regard to Au improved with the introduction of neutron activation techniques, flameless atomic absorption spectrometry and other methods; today analyses for $\mathrm{Au}$, $\mathrm{As}$ and $\mathrm{Sb}$ are carried out on a routine basis and at low cost with the result that these elements are commonly determined in geochemical surveys. The numerous analyses achieved worldwide have immensely improved our knowledge of the distribution of $\mathrm{Au}, \mathrm{As}$ and $\mathrm{Sb}$ as geochemical elements in the natural environment. This is also the case in Greenland where the Geological Survey of Denmark and Greenland analysed all systematically collected stream sediment samples by Instrumental Neutron Activation Analysis for a range of elements including $\mathrm{Au}, \mathrm{As}$ and $\mathrm{Sb}$. The large scale regional distribution patterns for the three elements are shown here for the first time, and their implications for gold exploration and for environmental issues are discussed.

\section{Outline of the geology}

The Precambrian of West and South Greenland comprises rock complexes from early Archaean to Mesoproterozoic in age (Escher \& Pulvertaft, 1995; see Kalsbeek 1994 for an overview containing the latest isotopic evidence). Most of the area consists of gneiss complexes of Archaean age which have been variably affected by Proterozoic deformation and metamorphism. Basic metavolcanic and metaplutonic rocks are common as enclaves within the Archaean gneisses throughout West Greenland, whereas intercalations of basic metavolcanic rocks together with metasediments occur at Taartoq, Nuuk and Torsukattak. Metaigneous and metasedimentary rocks formed during the Proterozoic occur in the three Palaeoproterozoic orogens, the Ketilidian in South Greenland, the Nagssugtoqidian, and the Rinkian from Torsukattak and northwards. In addition, Proterozoic platform volcano-sedimentary sequences occur in the Midternæs - Grænseland region in South-West Greenland (Fig. 1). South Greenland was further subjected to Mesoproterozoic rifting and alkaline magmatism within the Gardar province.

\section{Data acquisition and presentation}

The samples were collected under the Survey's reconnaissance geochemical mapping programme of Greenland. The programme uses systematically collected samples of stream sediment and stream water. The fine fractions $(<0.1 \mathrm{~mm})$ of the sediment samples are analysed for a minimum of 40 major and trace elements whereas the conductivity and fluoride concentration are determined in the water samples (Steenfelt, 1987,1993a). The results have hitherto been reported in GGU's Open File Series and Thematic Map Series (see list of 1994 publications included with this volume). However, each of these publications only covers a small section of Greenland, hence very large scale geochemical variations are not seen. The first compilation of stream sediment data from a contiguous area from Uummannaq to Kap Farvel was published by Steenfelt 
(1994a). It showed that the distribution patterns of the major elements $\mathrm{Ca}$ and $\mathrm{K}$ reflect important crustal boundaries such as suture zones between continents, and that the data can be used to characterise the tectono-stratigraphic elements of the Precambrian crust (Steenfelt, 1994b).

The 5635 stream sediment samples used in this presentation were collected over a period of 15 years (see Steenfelt, 1994a). Each sample is a composite of 3 to 10 subsamples collected at different places in the stream bed along 10 to $50 \mathrm{~m}$ of the stream course. The sampling density is 1 sample per $6 \mathrm{~km}^{2}$ in western South Greenland and 1 sample per 20 to $30 \mathrm{~km}^{2}$ in other areas. Samples were analysed for As, Sb and Au by Instrumental Neutron Activation Analysis (INAA) at Activation Laboratories Ltd or by Bondar-Clegg Laboratories, both in Canada. The lower limit of detection for the analyses is $5 \mathrm{ppb}$ for $\mathrm{Au}, 2 \mathrm{ppm}$ for As and $0.2 \mathrm{ppm}$ for $\mathrm{Sb}$.

The results are displayed as dot maps (Figs 1,2) where each dot represents a sample location where the concentration is above detection limit; the dot size is proportional to the measured concentration. The scaling of the dot size is chosen so that the regional variations are illustrated as well as possible. Table 1 lists statistical parameters for the data together with estimates of the crustal abundance of the elements.

Table 1. Percentiles of Au, As and Sb concentrations in stream sediment samples from West and South Greenland

\begin{tabular}{cccc}
\hline$\%$ & $\begin{array}{c}\text { Au } \\
\text { ppb }\end{array}$ & $\begin{array}{c}\text { As } \\
\text { ppm }\end{array}$ & $\begin{array}{c}\text { Sb } \\
\text { ppm }\end{array}$ \\
\hline 10 & 0 & 0 & 0 \\
20 & 0 & 0 & 0 \\
30 & 0 & 0 & 0 \\
40 & 0 & 0 & 0 \\
50 & 0 & 0 & 0 \\
60 & 0 & 0 & 0 \\
70 & 0 & 2 & 0.2 \\
80 & 0 & 4 & 0.4 \\
90 & 6 & 9 & 0.6 \\
95 & 9 & 16 & 0.9 \\
98 & 15 & 40 & 1.4 \\
99 & 26.5 & 71 & 1.8 \\
& & & \\
av* & 3.89 & 3.53 & 0.23 \\
max & 850 & 1100 & 36.4 \\
\hline
\end{tabular}

* see text for method of calculation

\section{Average abundances}

Figures for crustal abundances of elements may be useful for studies of crust-mantle relationships, for global massbalance calculations, and as a basis for chemical comparisons between various parts of the crust. However, published figures (e.g. Taylor, 1964; Wedepohl, 1969-1979; Taylor \& McLennan, 1985) are all estimates based on limited numbers of samples. As more analytical data emerge these estimates may need revision. The region dealt with here represents a substantial proportion of the Precambrian crust of Greenland and the average concentrations for $\mathrm{Au}, \mathrm{As}$ and $\mathrm{Sb}$ may, therefore, contribute to the improvement of existing estimates for crustal abundance.

Many of the measured concentrations are below the detection limits for the three elements (Table 1), hence it is not possible to obtain true average figures or to display the true geochemical background variation throughout the region. An estimate of the true average has been obtained by assuming that the average of element concentrations below detection limit is equal to half the value of the detection limit: $2.5 \mathrm{ppb}$ for $\mathrm{Au}, 1 \mathrm{ppm}$ for As and $0.1 \mathrm{ppm}$ for $\mathrm{Sb}$. The resulting average abundance estimates for the three elements in stream sediment are then $3.89 \mathrm{ppb}$ Au, $3.53 \mathrm{ppm}$ As and $0.23 \mathrm{ppm} \mathrm{Sb}$ for the Precambrian of West and South Greenland. Equal area representation was used in the calculation of these figures to ensure that the result is not biased by the higher density of samples in western South Greenland.

The abundance of the three elements in the upper crust is estimated by Taylor \& McLennan (1985) at $1.8 \mathrm{ppb} \mathrm{Au}$, $1.5 \mathrm{ppm}$ As and $0.2 \mathrm{ppm} \mathrm{Sb}$. The figures from West and South Greenland agree for $\mathrm{Sb}$ but are considerably higher for $\mathrm{Au}$ and As. The higher $\mathrm{Au}$ abundance in stream sediment is expected because gold grains are resistant to weathering and their abundance increases in the stream environment relative to that of the surrounding rocks.

Geochemical data from a comparable section of Precambrian crust is provided by the Geochemical Atlas of Finland (Koljonen, 1992). The averages of $c .300$ till samples collected systematically over the whole of Finland are $1.2 \mathrm{ppb} \mathrm{Au}, 3.3 \mathrm{ppm} \mathrm{As}$, and $0.3 \mathrm{ppm}$ Sb. Again As averages are much higher than the estimate by Taylor \& McLennan (1985) and this leaves the possibility that they have underestimated the magnitude of As mineralisation in the upper crust. Otherwise it must be concluded that the two areas of Precambrian crust are enriched in As.

\section{Distribution patterns in relation to geology}

The maps demonstrate that the three elements $\mathrm{As}, \mathrm{Sb}$ and $\mathrm{Au}$ are very unevenly distributed over West and South Greenland and also that there are significant differences in 
their distribution patterns (Figs 1, 2). The As distribution shows a small number of well defined high-As provinces, the $\mathrm{Sb}$ distribution shows several clusters but also some scatter, whereas the Au distribution appears to be the most even with poorly outlined clusters and elevated values scattered over the entire region.

The high As provinces and clusters are clearly associated with certain rock complexes: the Archaean supracrustal rocks around Torsukattak in the north and at Taartoq in the south, the Proterozoic supracrustal rocks in Midternæs Grænseland, and the southern supracrustal sequences of the Ketilidian orogen. The common feature of these rock complexes is that they comprise metasediments interlayered with volcanic rocks. In addition, elevated As values occur associated with mafic to ultramafic rocks near Paamiut, and scattered high values occur within the granite dominated part of the Ketilidian orogen. In the remaining part of Greenland the stream sediments have very low concentrations of As, close to or below $2 \mathrm{ppm}$. The Nagssugtoqidian orogen is also largely barren with the exception of a few samples derived from mafic metavolcanics in the Nordre Strømfjord shear zone. This is in strong contrast to the high As signature of the Ketilidian orogen.

Thus, it appears that high As characterises volcano-sedimentary deposits of both Archaean and Proterozoic ages. Other supracrustal sequences characterised by high As concentrations include the Palaeoproterozoic Karrat Group of meta-greywackes north of Uummannaq (Thomassen, 1992) and equivalent formations within the Foxe fold belt on Baffin Island (Cameron, 1986), the Neoproterozoic Eleonore Bay Supergroup in East Greenland (Steenfelt, 1993b) and the equivalent Dalradian in Scotland (Plant et al., 1991). Based on comparative studies of supracrustal sequences Simpson et al. (1989) have suggested that build up of As concentrations is characteristic of rapidly subsiding extensional basins where As is supplied by volcanic emissions and is retained by organic, sulphur-rich compounds. The As abundance may therefore be seen as an indicator of a certain type of geological environment, which in Greenland distinguishes the supracrustal sequences at Taartoq and Torsukattak from all other Archaean supracrustal formations.

The distribution of $\mathrm{Sb}$ is far less relatable to particular lithological units than is the case for As. In South Greenland the clusters of high Sb values largely, but not entirely, coincide with the high As province and anomalies; the distribution patterns of $\mathrm{As}$ and $\mathrm{Sb}$ in South Greenland are shown in greater detail in Steenfelt \& Tukiainen (1991). Further north significant discrepancies are noted between As and Sb concentrations. The As-rich Midternæs volcanosedimentary sequence is low in $\mathrm{Sb}$ as are the mafic rocks east of Paamiut, whereas $\mathrm{Sb}$ anomalies occur in As-low areas just north and south of Paamiut.
Scattered $\mathrm{Sb}$ anomalies occur between Nuuk and Sisimiut in the As-barren region dominated by Archaean orthogneiss. The small Sb cluster at the Sarfartôq carbonatitekimberlite occurrence suggests that ultrapotassic rocks such as kimberlites and lamprophyres may be the source of the Sb. In fact the entire region east of Maniitsoq is a province of kimberlite and lamprophyre dykes (Larsen \& Rex, 1992). At Torsukattak the $\mathrm{Sb}$ anomalous samples are derived from both Archaean and Proterozoic rock complexes, unlike the high As samples which are confined to the Archaean rocks in that area. The introduction of Sb to the Proterozoic sediments could reflect a remobilisation of Sb-bearing deposits in Archaean layers, or could be caused by ultrapotassic magmatism as discussed by Steenfelt (1992).

A great deal of 'noise' in the Au analytical results is expected for the following reasons: (1) The minute but dense gold grains are very irregularly distributed in the stream bed leading to non-representative sampling. (2) Sample amounts submitted for analysis are very small ( 1 to $7 \mathrm{~g}$ ), so that measured gold concentrations are poorly representative of the entire sample ('nugget effect'), particularly at low concentrations. (3) Analytical precision is poor close to the detection limit.

These uncertainties imply that where gold is detected in stream sediment samples there has to be gold in the stream surroundings, but the actual values obtained in the samples cannot be considered proportional to the quantities of gold in the drainage basin. On the other hand, the absence of gold in a sample does not necessarily mean that there is no gold in the area. At the scale of this presentation the scattered $5 \mathrm{ppb}$ samples may be disregarded and attention focused on the distribution of higher values.

The elevated $\mathrm{Au}$ values are scattered over most of the map area with higher density towards north and south. A large proportion of the Au anomalies fall within the high As provinces, but many high Au values do not coincide with either high As or high Sb. Nor do they appear to be related to any particular rock complex or any particular geological environment.

\section{Implications for mineral exploration}

Arsenic and Sb are both brought to the surface environment by volcanic activity. Owing to their affinity with sulphur and carbon they are retained in organic-rich sedimentary basins, particularly under reducing conditions. This is expressed in abundance figures for As and $\mathrm{Sb}$ in various rock types (Table 2). The behaviour of Au is less well known, but it may be assumed that Au follows As and $\mathrm{Sb}$ and is upgraded in organic-rich sedimentary environments. Such sedimentary deposits can be regarded as crustal reservoirs for $\mathrm{Au}, \mathrm{As}, \mathrm{Sb}$ and other elements with similar 
behaviour (e.g. $\mathrm{Mo}, \mathrm{Cu}, \mathrm{Bi})$ which may then act as source rocks for later mineralisation (Simpson et al., 1989). The Greenland data suggest that the south-eastern Ketilidian sedimentary basin constitutes a typical crustal reservoir for Au with a potential for formation of gold deposits during later remobilisation and redeposition. Recent field work within the SUPRASYD programme has confirmed $\mathrm{Au}$ and As enrichment in graphite and sulphide rich pelitic layers, and several Au mineralised veins, with and without As, have been located in second-order structures adjoining major shear zones (Garde \& Schønwandt, 1995; Stendal et al., 1995). One gold vein prospect with economic potential is known (Petersen \& Pedersen, 1995), but the large number of samples with elevated and high Au concentrations within the high As province (Fig. 1) strongly suggests that more deposits of this kind are to be expected.

Antimony is known to be easily mobilised from its primary setting through transportation by and redeposition from hot hydrous solutions. Consequently, the present distribution pattern of $\mathrm{Sb}$ is likely to outline areas of hydrothermally mineralised fracture systems centred on late granitic, alkaline or perhaps lamprophyric/kimberlitic magma intrusions. In areas where a supracrustal source of $\mathrm{Sb}$ is missing the magmas themselves may be assumed to have supplied the Sb. In many documented cases Au has also been mobilised and redeposited during hydrothermal activity. However, the lack of spatial correlation between $\mathrm{Au}$ and $\mathrm{Sb}$ anomalies over West and South Greenland outside the Ketilidian sedimentary basin suggests that $\mathrm{Sb}$ alone is not a useful pathfinder element for gold.

Even slight elevations in Au and As may be significant and reflect economic gold mineralisation, e.g. the small As and Au anomalies at Storø (Fig. 2) where a promising gold prospect is being drilled (Petersen et al., 1995). The gold prospect occurs in the sheared boundary zone between the Akulleq and Akia terranes, and the other gold anomalies along this boundary suggest that gold mineralisation may also be found in other parts of this zone.

Pathfinder elements outline one type of environment with gold potential, but the Au

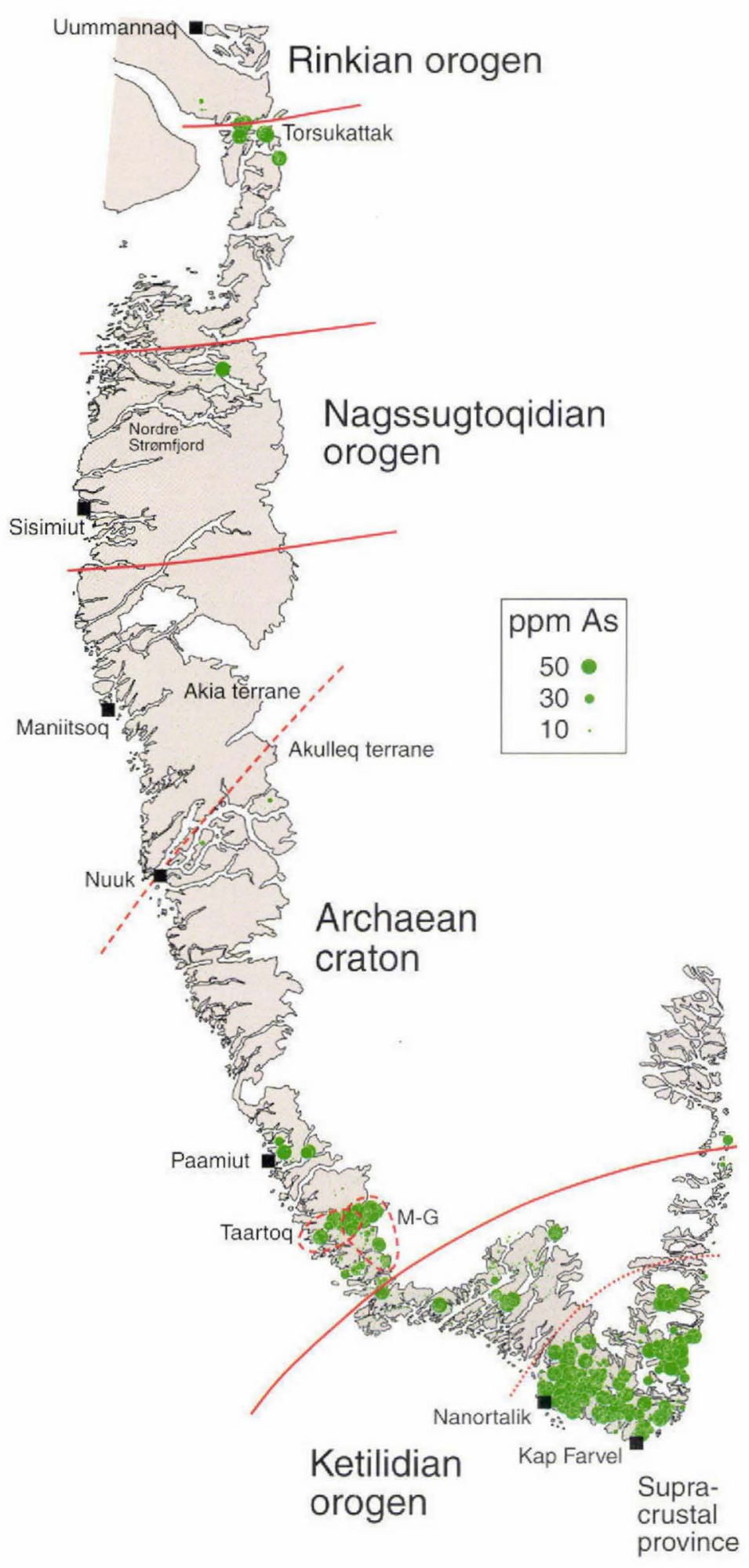

Fig. 1. Arsenic concentrations of the $<0.1 \mathrm{~mm}$ grain size fraction of stream sediment samples. Instrumental neutron activation analysis. M-G: Midternas Grænseland. 


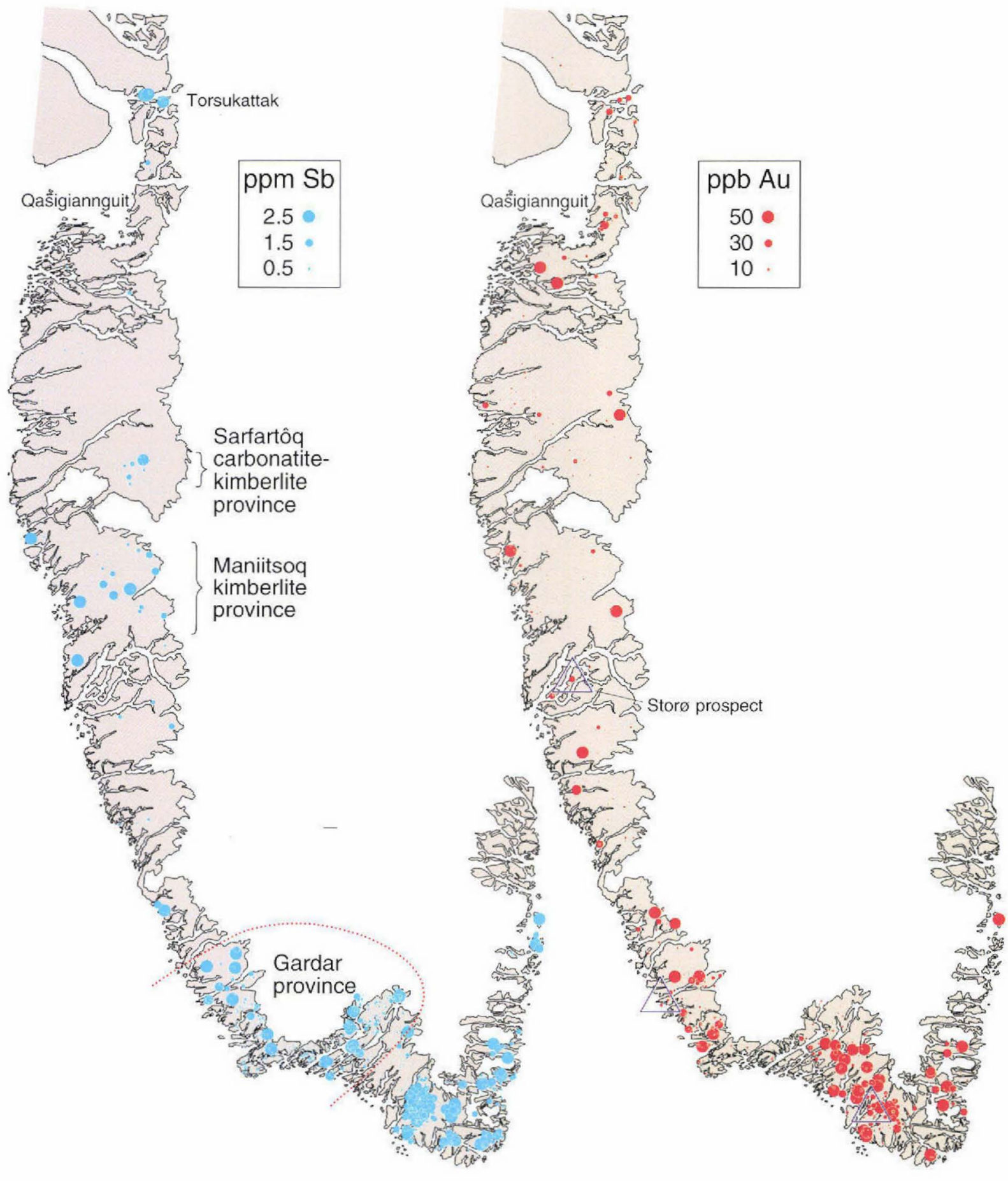

Fig. 2. Antimony $(\mathrm{Sb})$ and gold $(\mathrm{Au})$ concentrations of the $<0.1 \mathrm{~mm}$ grain size fraction of stream sediment samples. Instrumental neutron activation analysis. Drilled gold prospects are shown by open triangles. 
Table 2. Abundance of Au, As and Sb in common rock types (Govett, 1983) and estimates of crustal abundance (Taylor \& McLennan, 1985)

\begin{tabular}{lccc}
\hline & Au ppb & As ppm & Sb ppm \\
\hline Igneous rocks & & & \\
Mafic & 4 & 2 & 1.0 \\
Intermediate & 1 & 2.4 & 0.2 \\
Felsic & 1 & 0.25 & 0.1 \\
Sedimentary rocks & & & \\
Shale & 1 & 6.6 & 2.0 \\
& & & \\
Upper crust & 1.8 & 1.5 & 0.2 \\
Crust & 3.0 & 1.0 & 0.2 \\
\hline
\end{tabular}

distribution itself suggests that a number of other types of mineralisation have taken place in various parts of Greenland. More studies are warranted to evaluate the significance of many of the scattered Au anomalies, but a few comments can be made at this stage. Thus fault systems and alteration zones associated with Mid-Proterozoic Gardar rifting and magma intrusion are suggested as possible sites for gold mineralisation. A cluster of elevated Au values associated with a sequence of metasediments near Qasigiannguit suggests that some kind of gold mineralisation has taken place there (see also Steenfelt, 1992).

\section{Implications for environmental management}

Both $\mathrm{As}$ and $\mathrm{Sb}$ belong to the group of elements which are potentially toxic in high concentrations, hence many government authorities have decided on upper limits for permitted concentrations of these elements in soil, water, industrial waste, crops etc. The value chosen as the upper acceptable limit for a particular element is typically based on the average abundance of this element in a given natural medium, e.g. soil and water. However, the geochemical maps of $\mathrm{As}$ and $\mathrm{Sb}$ show that the regional variation in the natural geochemical background is so large that the use of any average figure as a measure of the natural background at a particular place is meaningless. For example, industrial waste containing 10 ppm As would be 10 times 'dirtier' than the natural background in the Maniitsoq district, but would be about 4 times 'cleaner' than the average natural background in the Nanortalik district.

Pollution, defined as artificial additions to nature which raise the concentration of a particular element to a level above the natural background, cannot be defined properly without documentation of the regional variations in the element concentrations. The geochemical maps presented here provide such a documentation on a regional scale and also serve to outline areas where the natural concentration of a particular element may warrant attention from the authorities. In the case of potentially toxic elements such as $\mathrm{Sb}$, $\mathrm{Cd}$ and $\mathrm{Pb}$ concern should be directed to areas of high concentrations, whereas in the case of elements with nutritional value such as $\mathrm{K}, \mathrm{Mg}$ and $\mathrm{Zn}$ it is important to identify areas where abnormally low concentrations may cause deficiency problems for plants and plant eating animals.

Data on soil may be considered more relevant to environmental research than stream sediment data. However, studies of stream sediment and soil analyses from within the same area show that element concentration levels for the two media are similar. Only elements such as $\mathrm{Zr}, \mathrm{Y}, \mathrm{Th}$, which are essentially contained in weathering resistant, accessory minerals, are enriched in stream sediment relative to the surrounding soil.

\section{Conclusion}

The compilations of $\mathrm{Au}, \mathrm{As}$ and $\mathrm{Sb}$ data over large parts of the Precambrian of West and South Greenland provide an overview of large scale distribution patterns which are relevant to geological interpretation, mineral exploration and environmental monitoring. The large datasets also contribute to improving estimates of crustal element abundances.

South Greenland stands out as being particularly enriched in all three elements, which is interpreted to reflect primary accumulation of the elements in Palaeoproterozoic volcanosedimentary basins with subsequent remobilisation and redeposition during both the Ketilidian orogeny and the Mesoproterozoic Gardar rifting and alkaline magmatism. Arsenic and Sb may be used as pathfinders for $\mathrm{Au}$ in this province and in Archaean greenstone belts, but the Au distribution suggests that a number of other types of gold mineralisation exist which are not associated with either high As or high Sb.

The documentation of the uneven distribution of As and $\mathrm{Sb}$ is essential to environmental management and shows the importance of knowing the local natural background concentrations at the site where environmental impacts of human activities are considered.

Acknowledgements. Many people, including field and helicopter crews, laboratory personnel, students, and colleagues, have contributed to the acquisition of the samples, their preparation and analysis, and the data management. They are all acknowledged for their work and dedication. Else Dam, in particular, has been an invaluable support in all phases of the reconnaissance geochemical mapping programme. The Mineral Resource Administration for Greenland and Nunaoil A/S have contributed financially to minor parts of the programme. 


\section{References}

Boyle, R. W. 1979: The geochemistry of gold and its deposits. Bull. Geol. Surv. Can. 280, 584 pp.

Cameron, E. M. 1986: An introduction to the interpretation of data from central Baffin Island, district of Franklin. Ottawa: Geological Survey of Canada. 21 pp.

Chadwick, B. \& Garde, A. A. in press: Palaeozoic oblique plate convergence in South Greenland: a re-appraisal of the Ketilidian orogen. In Brewer, T. S. \& Atkin, B. P. (ed.) Spec. Pub. Geol. Soc., London.

Escher, J. C. \& Pulvertaft, T. C. R. 1995: Geological map of Greenland, 1:2 500000 . Copenhagen: Geological Survey of Greenland.

Garde, A. A. \& Schønwandt, H. K. 1995: Project SUPRASYD 1994 - Ketilidian supracrustal rocks in South-East Greenland and gold-bearing shear zones in the Julianehåb batholith. Rapp. Grønlands geol. Unders. 165, 59-63.

Govett, G. J. S. (ed.) 1983: Rock geochemistry in mineral exploration. Handbook of exploration geochemistry, 3. Amsterdam: Elsevier.

Kalsbeek, F. 1994: Archaean and early Proterozoic basement provinces in Greenland. Rapp. Grønlands geol. Unders. 160, $37-40$.

Koljonen, T. (ed.) 1992: The geochemical atlas of Finland, Part 2: Till. Espoo: Geological Survey of Finland.

Larsen, L. M. \& Rex, D. C. 1992: A review of the 2500 Ma span of alkaline-ultramafic, potassic and carbonatitic magmatism in West Greenland. Lithos 28, 367-402.

Petersen, J. S. \& Pedersen, J. L. 1995: Geological setting of Proterozoic gold mineralization in the Nanortalik Peninsula, South Greenland. Open File Ser. Grønlands geol. Unders. 95/10, 69-72.

Petersen, J. S., Pedersen, N. H. \& Grahl-Madsen, L. 1995: Gold mineralization and stratiform iron formation at Storø, West Greenland. Open File Ser. Grønlands geol. Unders. 95/10, 73-75.

Plant, J. A., Cooper, D. C., Green, P. M., Reedman, A. J. \& Simpson, P. R. 1991: Regional distribution of $\mathrm{As}, \mathrm{Sb}$ and $\mathrm{Bi}$ in the Grampian Highlands of Scotland and English Lake district: implications for gold metallogeny. Trans. Inst. Min. Metall. 100 , B135-B147.

Simpson, P. R., Gallagher, M. J., Green, P. M., Middleton, R. S., Raiswell, R., Slater, D. \& Williams, R. A. C. 1989: Gold mineralization in relation to the evolution of extensional volcanosedimentary basins in the Scottish Dalradian and the Abitibi Belt, Canada. Trans. Inst. Min. Metall. 98, B102-B117.
Steenfelt, A. 1987: Geochemical mapping and prospecting in Greenland - an overview of results and experience. J. geochem. Explor. 29, 183-205.

Steenfelt, A. 1992: Gold, arsenic and antimony in stream sediment related to supracrustal units between Arfersiorfik and Qarajaq Isfjord $\left(68^{\circ} \mathrm{N}\right.$ to $\left.70^{\circ} 30^{\prime} \mathrm{N}\right)$, West Greenland. Open File Ser. Grønlands geol. Unders. 92/4, $11 \mathrm{pp}$.

Steenfelt, A. 1993a: Geochemical mapping - progress in Greenland. J. geochem. Explor. 49, 5-13.

Steenfelt, A. 1993b: Stream sediment geochemical evidence for gold mineralisation in Hudson Land $\left(73^{\circ} 10^{\prime}\right.$ to $74^{\circ} 25^{\prime} \mathrm{N}, 21^{\circ} 30^{\prime}$ to $24^{\circ} 25^{\prime} \mathrm{W}$ ), North-East Greenland. Open File Ser. Grønlands geol. Unders. 93/4, $25 \mathrm{pp}$.

Steenfelt, A. 1994a: Large scale geochemical variation in the Precambrian of West and South Greenland. Rapp. Grønlands Unders. 160, 41-44.

Steenfelt, A. 1994b: Crustal structure in West and South Greenland reflected by regional distribution patterns of calcium and potassium in stream sediment. Rapp. Gronlands Unders. 161, $11-20$.

Steenfelt, A. \& Tukiainen, T. 1991: Geochemical mapping: distribution of gold, arsenic, antimony and tantalum in South Greenland. Rapp. Grønlands Unders. 152, 55-61.

Stendal, H., Grahl-Madsen, L., Olsen, H. K., Schønwandt, H. K. \& Thomassen, B. 1995: Gold exploration in the early Proterozoic Ketilidian orogen, South Greenland. Explor. Mining Geol. 4, No. 3, 307-315.

Taylor, S. R. 1964: Abundance of chemical elements in the continental crust: a new table. Geochim. Cosmochim. Acta 28, 1273-1285.

Taylor, S. R. \& McLennan, S. M. 1985: The continental crust: its composition and evolution. Oxford: Blackwell Scientific Publications.

Thomassen, 1992: The gold and base metal potential of the Lower Proterozoic Karrat Group, West Greenland. Rapp. Gronlands geol. Unders. 155, 57-66.

Wedepohl, K. H. 1969-1979: Handbook of Geochemistry. Berlin: Springer-Verlag.

\section{A. S., Geological Survey of Denmark and Greenland, Copenhagen}

